\title{
HIPERPLASIA CONGÊNITA DE SUPRA-RENAL: A COMPREENSÃO DODIAGNÓSTICO E IMPLICAÇÕES PARA A AUTO-IMAGEM
}

\author{
CONGENITAL ADRENAL HIPERPLASIA: THE DIAGNOSIS COMPREHENSION AND AUTO-IMAGE IMPLICATIONS
}

Fabíola C. R. Brunhara1 \& Eucia Beatriz Lopes Petean²

${ }^{1}$ Doutoranda. ${ }^{2}$ Docente. Faculdade de Filosofia, Ciências e Letras de Ribeirão Preto - USP.

Correspondencia: Av. Bandeirantes, 3900 - CEP 14040-901 - Fone: 602-3767 Fax: 603-3793 - e-mail: ebpetean@ffclrp.usp.br

BRUNHARA FCR \& PETEAN EBL. Hiperplasia congênita de supra-renal: A compreensão do diagnóstico e implicações para a auto-imagem. Medicina, Ribeirão Preto, 36: 45-53, jan./mar. 2003.

RESUMO: A Hiperplasia Congênita de Supra-Renal (HCSR) é uma síndrome genética, que caracteriza uma condição de intersexualidade. No intuito de compreender o que as mulheres conhecem sobre a síndrome, foram entrevistadas sete mulheres portadoras de HCSR, com idades entre 18 e 40 anos, de baixo nível sociocultural, dentre as quais 5 realizaram cirurgia corretiva de genitália, sendo 3 casadas e 4 solteiras. Os resultados indicaram entendimento sobre a síndrome. As 4 mulheres solteiras não iniciaram vida sexual e 3 delas colocaram a síndrome como principal dificuldade. Todas referiram satisfação com a cirurgia corretiva, não sofrendo prejuízos relacionados ao prazer e orgasmos, porém têm dificuldades relacionadas à auto-imagem.

UNITERMOS: Hiperplasia Supra-Renal Congênita. Diagnóstico Psicológico. Auto Imagem.

\section{1- INTRODUÇÃO}

As bases da discussão da diferenciação sexual são fisiológicas, psicológicas e sociológicas. O que se deve distinguir é o sexo genético, o sexo gonadal, o sexo corporal, o sexo do estado civil e, finalmente, o sexo "vivido". Esse sexo "vivido" remete à noção de identidade sexuada, na qual o indivíduo se reconhece, e inclui dois componentes: a identidade de gênero e a identidade de sexo. Por identidade de sexo, compreende-se um conceito biológico, e por identidade de gênero, o senso de conhecimento de a qual sexo se pertence, isto é, a consciência de que "eu sou homem" ou "eu sou mulher" (1).

A aquisição, na criança, da identidade de gênero é precoce, entre 2 e 4 anos, e é produto de duas forças: biológica e psicossocial. A força biológica decorre da presença do cromossomo Y, que acrescenta uma pulsão andrógina no tecido feminino, para iniciar o processo de masculinização. A segunda categoria de forças advém de uma série quase infinita, de indícios derivados das experiências com os membros da família, professores, amigos e companheiros, e de fenômenos culturais.

Segundo Bee $(1997)^{(2)}$, depois de adquirida a identidade de gênero em si, a estabilidade de gênero é a segunda etapa, com mais ou menos quatro anos de idade, e consiste na compreensão de que se permanece do mesmo gênero por toda a vida. A última etapa é a consistência de gênero, que é o reconhecimento de que alguém permanece com o mesmo gênero, mesmo que possa parecer ter mudado o comprimento do cabelo ou vestindo roupas diferentes. A constância de gênero é entendida mais ou menos aos 5 anos e é, nesse momento, que a criança procura uma "regra" sobre a maneira pela qual meninos e meninas se comportam, tratando essas "regras", inicialmente, como absolutas, mas, depois, esses estereótipos podem reduzir-se um pouco ${ }^{(2)}$. 
As pessoas que sentem sofrimento intenso e persistente, desconforto recorrente e um senso de inadequação relativo ao sexo típico, querendo pertencer ao outro sexo, apresentam Transtorno de Identidade de Gênero. De acordo com o DSM-IV (1995) ${ }^{(3)}$ há dois componentes no Transtorno da Identidade de Gênero, sendo que ambos devem estar presentes para ser feito o diagnóstico. Deve haver evidências de uma forte e persistente identificação com o gênero oposto, que consiste no desejo de ser, ou na insistência do indivíduo de que ele é do sexo oposto (Critério A). A identificação com o gênero do sexo oposto não deve refletir um mero desejo de quaisquer vantagens culturais, percebidas por ser do outro sexo. Também deve haver evidências de um desconforto persistente com o próprio sexo atribuído ou uma sensação de inadequação no papel de gênero de tal sexo (Critério B). O diagnóstico não é feito, se o indivíduo tem uma condição intersexual física concomitante (por ex., síndrome de insensibilidade aos andróginos ou hiperplasia congênita de supra-renal) (Critério C). Para que o diagnóstico seja feito, deve haver evidências de sofrimento clinicamente significativo ou prejuízo no funcionamento social ou ocupacional ou em outras áreas importantes na vida do indivíduo (Critério D).

Atualmente, o termo intersexualidade é usado, quando não há correspondência entre a gônada e a genitália interna ou externa. Esse transtorno inclui uma variedade de síndromes, dentre elas a Síndrome Adrenogenital (ou Hiperplasia Congênita de SupraRenal - HCSR).

A HCSR é uma síndrome genética, autossômica recessiva, da família das desordens na síntese dos esteróides. Em $90 \%$ dos casos, a HCSR é causada pela deficiência de uma enzima, a 21-hidroxilase, encontrada no córtex da glândula adrenal e fundamental na síntese dos glicocorticóides. Decorrente das baixas concentrações circulantes de cortisol, há um aumento na secreção do ACTH, com produção elevada dos precursores do cortisol e desvio na esteroidogênese, com produção exclusiva de andróginos.

Nas mulheres, esses andróginos adrenais, fetais, excessivos causam androgenização ou masculinização da genitália externa, variando desde um leve aumento clitoriano até a fusão dos lábios externos que ficam com aparência de uma genitália masculina. No entanto, apesar da genitália externa ambígua, existem vagina, útero, trompas e ovários. A HCSR clássica é apresentada em duas formas: a perdedora de sal, mais grave, consequiência da deficiência de aldosterona e conseqüente diminuição do nível do sódio no sangue e aumento do potássio, provocando, assim, uma descompensação metabólica com graves episódios de desidratação; e a não perdedora de sal, que resulta numa virilização simples.

As mulheres não tratadas podem sofrer sintomas androgênicos tais como acne, problemas menstruais ou síndrome do ovário micropolicístico (hirsutismo, obesidade, virilização, amenorréia, resistência insulínica). O tratamento envolve plástica corretiva de genitália externa, reposição de hidrocortisona desde a infância, podendo, nas formas perdedoras de sal, ser acrescentada a reposição de mineralocorticóide e adicionado sal na dieta.

A extensão em que as terapêuticas para HCSR interferem na identidade sexual das mulheres ainda é muito pouco conhecida. Há a hipótese de que, devido à cirurgia de reconstrução da genitália, essas mulheres percam uma área erógena importante no desenvolvimento da sexualidade. Meyer Bahlburg et al. $(1996)^{(4)}$ estudaram quatro casos clássicos de HCSR e seus dados demonstram que todas as mulheres perderam zona erógena, ficando praticamente anorgásmicas. No entanto, o estudo de Vates et al. (1999) ${ }^{(5)}$ mostra que a maioria das mulheres que foram operadas não apresentam problemas físicos, entretanto têm dificuldades com relações interpessoais e intimidades sexuais.

Desordens de identidades de gênero e gênero desviante são evidentes em mulheres portadoras de HCSR, de acordo com os estudos de Slipper \& Drop $(1998)^{(6)}$. Zucker et al. $(1996)^{(7)}$ corroboram os estudos de Slipper \& Drop e também observaram que as mulheres com HCSR referem mais comportamento de gênero cruzado e desconforto em relação ao senso de feminilidade durante a infância, no entanto, discutem a exposição prematura aos andróginos, como determinantes desses comportamentos.

Alherbish et al. $(1996)^{(8)}$ demonstraram a preferência dos pais para que seus filhos, que nasceram com genitália ambígua, não realizassem cirurgia corretiva, pois recusaram a nova condição de seus filhos, como feminina. Em um outro trabalho, os mesmos autores (Alherbish et al., 1996) ${ }^{(9)}$ relacionaram a recusa dos pais a razões socioculturais e ao diagnóstico tardio.

Assim, devido às posições dicotômicas, biológicas e psicossociais, apresentadas pelos trabalhos que procuram explicar o comportamento das mulheres com HCSR, objetivou-se, num trabalho mais 
amplo, buscar uma compreensão global do desenvolvimento psicossexual de mulheres com HCSR, atendidas no Hospital das Clínicas da Faculdade de Medicina de Ribeirão Preto da Universidade de São Paulo (HCFMRP-USP). Nesse sentido, foi importante conhecer o que essas mulheres sabem da problemática de sua doença, quais as dificuldades em lidar com ela e as implicações para sua vida sexual e imagem corporal, dados apresentados neste artigo.

\section{2- MÉTODO}

Foram entrevistadas, seguindo um roteiro semiestruturado, 7 mulheres maiores de 18 anos, portadoras de HCSR, pacientes do Ambulatório de Determinação e Diferenciação Sexual (DDS), de responsabilidade do Departamento de Genética Médica do HCFMRP-USP. Essa equipe é composta por uma equipe multidisciplinar, que envolve médicos geneticistas, ginecologistas, endrocrinologistas, urologistas, cirurgiões pediátricos, radiologistas e psicólogos.

A análise das entrevistas foi qualitativa, de conteúdo temático, descrito por Minayo $(1994)^{(10)}$ e Valles $(1997)^{(11)}$.

\section{1- Participantes Do Estudo}

Para maior facilidade na caracterização de cada uma das mulheres portadoras de HCSR, foram atribuídas a elas nomes fictícios.

SUSI: 40 anos, portadora de HCSR, não perdedora de sal. Realizou "amputação parcial de clitóris e plástica" aos 17 anos, para amputação de clitóris. Tem terceiro grau completo. É escrivã de polícia. Casada. Têm uma filha com 10 anos, que herdou a síndrome. Renda mensal de mais ou menos um mil reais (6.62 salários mínimos).

LENA: 36 anos, portadora de HCSR, não perdedora de sal, não efetuou cirurgia corretiva de genitália externa. Estudou até a sexta série do primeiro grau. É 'do lar'. Casada. Tem 4 filhos. A renda mensal da família de três e meio salários mínimos ( $\mathrm{R} \$ 528,50)$.

TAÍS: 20 anos, portadora de HCSR, perdedora de sal. Realizou "exerese de sinéquia de pequenos lábios" aos 4 anos. Cursou até a oitava série do primeiro grau. Do lar, casada. Não soube informar a renda familiar.

DORA: 19 anos, portadora de HCSR, perdedora de sal. Efetuou "construção cirúrgica de vagina devido a diagnóstico de intersexo", com 3 anos, e neovaginoplastia aos 12 anos. Estava cursando a sex- ta série do primeiro grau. Solteira. Não soube informar a renda familiar.

LIA: 18 anos, portadora de HCSR, perdedora de sal. Efetuou duas cirurgias corretivas de genitália, uma para amputação de clitóris, com 4 anos, e outra, com 17 anos de idade, para abertura do seio urogenital. Sua escolaridade é de segundo grau completo. Trabalha como auxiliar, numa loja de brinquedos. Solteira. Não soube informar a renda familiar. Sua própria era de mais ou menos trezentos reais (2 salários mínimos).

LARA: 18 anos de idade, portadora de HCSR, perdedora de sal. Realizou "amputação segmentar de clitóris, abertura de seio urogenital e plástica genital". Foi registrada como menino. Estudou até a sétima série do primeiro grau e só fica em casa (não tem nenhuma profissão ou ocupação). Solteira. Não soube informar a renda familiar.

BETE: 18 anos, portadora de HCSR, não perdedora de sal. Não fez correções cirúrgicas. Estava cursando o quarto ano de magistério. Trabalhava numa loja de frios, solteira, com renda pessoal de um e meio salário mínimo (R $\$ 226,50)$.

\section{3- RESULTADOS}

Do Levantamento dos Casos de HCSR, no HCFMRP-USP.

Os casos listados de HCSR, obtidos através do levantamento efetuado junto ao serviço de informática do Hospital das Clínicas (SCD-PRODESP), entre ambulatoriais e de enfermaria, no período de 1981 a 1998 , compreenderam cento e trinta e nove ocorrências.

Quando se realizou o corte, tendo como base a idade (igual ou maior de 18 anos), conseguiu-se obter 38 prontuários de pacientes que apresentavam diagnóstico ou suspeita diagnóstica de HCSR.

$\mathrm{Na}$ análise dos 38 prontuários, somente 14 pacientes portadoras de HCSR, maiores de 18 anos, enquadravam-se nos critérios deste estudo. Das 14, 7 pacientes aceitaram a participação na pesquisa, sendo que as outras 7 ou recusaram verbalmente a participar ou não compareceram à entrevista.

\section{Das Entrevistas}

O que sabe sobre a HCSR contempla a primeira explicação dada livremente sobre o entendimento da síndrome.

"Eu sei que a supra-renal minha não funciona, e... é a forma não perdedora de sal, e que tomando o remédio ela (supra-renal) se equilibra. 
O que eu sei, pelo menos a explicação que me deram (médicos) é que ela é louca, e o remédio transforma em normal..." (Susi)

"... que nasci como homem, e que aí trocaram para menina. Hoje sou menina normal..." (Dora)

Essas explicações basearam-se na classificação da doença (perdedora ou não perdedora de sal) e nos principais sintomas da HCSR, desde os implícitos à doença, como a disfunção da glândula supra-renal, até os explícitos decorrentes dessa disfunção, que podem ou não aparecer, tais como engrossar a voz, a hipertricose e a desidratação.

No primeiro momento, Taís, Dora e Lara remeteram-se ao aumento clitoriano, demonstrando a preocupação com essa questão do papel sexual, quando se reportaram ao "aqui embaixo muito grande", "que não sou homem nem nada", "que nasci como homem... hoje sou menina normal...”. Trouxeram, portanto, a dicotomia normal-anormal, presente no decorrer de todas as entrevistas, revelando esse aspecto biopsicossocial das relações das mulheres com HCSR.

Como ficou sabendo o diagnóstico, quem foi que contou e a partir de que momento tal diagnóstico foi apreendido.

“...quando eu era criança ninguém me falou nada, se me falou também eu não lembro, mas depois de grande foi que eu fiquei sabendo, apesar que eu não sei tudo, detalhes assim, sabe? Os médicos fala, fala, mas eu fico pensando e ah... acabo não entendendo nada..." (Taís)

"Minha mãe me contou. A hora que eu vi esse negócio aqui (clitóris aumentado), eu perguntei, né? Ela me explicou." (Lara)

As verbalizações oferecem indícios de que a apreensão do problema vem com o passar dos anos, que, mesmo sofrendo as intercorrências da doença durante a infância, pouco foi preservado. Questiona-se se esse fato é decorrente do próprio nível de compreensão infantil, se não há registro das informações ou se essas são passadas de uma forma tão complexa que não trazem a compreensão por parte das crianças.

A adolescência, portanto, mostrou-se como o período em que as mulheres buscaram a compreensão da problemática e apresentaram interesse nas explicações oferecidas ora pelo médico ora pelos familiares, na pessoa da mãe, que, quase sempre era quem as acompanhava aos atendimentos médicos.
O que sentiu, quando ficou sabendo, aborda os sentimentos vivenciados no momento em que souberam ser portadoras de HCSR.

"Olha, é... é... é difícil, porque tinha, eu... eu tinha uma certa diferença das demais pessoas, mas eu sempre encarei numa boa, eu sempre encarei isso numa boa... Então num... tinha a anormalidade mas pra mim isso nunca atrapalhou... atrapalhava, atrapalhava, não como ser normal, mas não que isso me incomodasse realmente, não me incomodava." (Susi)

"Eu fiquei muito triste, porque, por causa do remédio, ficá tomando, né? (...) Agora tá bom, vou me conformá com isso. (...) Ah, eu sinto triste, eu achava que eu ia sê diferente das outras, né? Das outras menina... (Lara)

Essas falas trouxeram explicitamente a confusão, a dúvida, quanto à dicotomia normal-anormal, diferente-igual. Todas as participantes demonstraram sentirem-se diferentes, anormais. Ao mesmo tempo, buscam se conformar com a diferença, que parece vincular-se principalmente ao uso crônico do medicamento, bem como aos sintomas, que comumente esbarram no estereótipo masculino/feminino.

O tratamento abarca os procedimentos necessários à terapêutica médica da HCSR, como os exames de níveis hormonais, o uso prolongado de medicação e as cirurgias corretivas.

"Ah! Eu tomo remédio até hoje, né?" (Taís)

"Tomo remédio desde quando eu nasci, aí trocô quando acho que eu tinha quatro anos e... eu fiz uma cirurgia, duas eu fiz... uma eu fiz o ano passado." (Lia)

As participantes relataram que esses procedimentos, a realização das cirurgias corretivas e os exames de sangue para checar os níveis hormonais sangüíneos, necessários para a dose do medicamento, trazem um grande dispêndio emocional, já que, muitas vezes, são baseados em tentativa e erro.

Efeito colateral da medicação inclui as intercorrências, físicas, negativas, provenientes do uso crônico do medicamento, bem como os sintomas relacionados ao não uso.

"Olha, eu acho que o que mais mudou é que eu engordei bastante... até tento emagrecer, até tento uma dieta, mas não consigo emagrecer." (Lena)

"Eu não sei, eu sinto muito, eu já perguntei pro médico, mas, eu não sei, eu sinto muito sono, eu tenho bastante estria, ele fala que é por causa 
do remédio também, né? Eu tenho vasinho, manchas, eles falam que é tudo problema do remédio, né? Porque o remédio que eu tomo contém corticóide, né?" (Taís)

O principal efeito colateral relatado foi a obesidade. Os outros sintomas negativos aparecem, como sono, varizes e manchas na pele, descontrole de pressão arterial.

As participantes relataram a consciência dos efeitos do não uso da medicação, como a desidratação e o que sentiram frente a esse efeito.

Adesão à medicação é a percepção dos sintomas do não uso do medicamento e a decisão por continuar tomando o remédio.

"Então, nunca parei... Sempre tomei... " (Lia)

"Sempre tomei, desde pequenininha... É, parei pra emagrecê. Mas aí eu ví que não ia resolvê nada (...) Mas eu tenho vontade de pará. Ah, não! É muito chato tomá todo dia! (Lara)

Das 7 mulheres entrevistadas, 2, a Lena e a Lara, uma vez, decidiram parar o medicamento, numa tentativa 'empírica' de 'ver o que aconteceria'. A principal motivação para fazerem isso foi a obesidade e acabaram por constatar que o corticóide realmente as engordava bastante, no entanto, a relação custo-benefício fez com que retomassem o uso.

Procedimento cirúrgico contempla como foi a percepção dessas mulheres a respeito de tal conduta médica.

"Não. Não tenho lembrança... a gente lembra quando a coisa é ruim, né? As coisas boas a gente esquece fácil, né? (...) Era um negócio que incomodava... era um... aumento no clitóris que, coisa que não podia, depois que fez ficou normal, norma, normal... aliás... o cirurgião que fez deve ser, não sei quem foi, mas foi muito bom, muito bom..." (Susi)

Fiz duas, uma quando era nenem e outra quando tava com 11 anos. (...) Não sei falar... (...) é pra abrir a vagina, porque a menstruação tinha parado e não descia." (Dora)

Elas se referiram à cirurgia que relizaram quando crianças com uma linguagem infantil, o que ficou evidenciado pela 'pelinha que tiveram que cortar'. Em contraposição, há o caso da Susi, que realizou essa cirurgia com 17 anos e se referiu a ela como 'amputação de clitóris', o que possibilitou que se questione como foram passadas, pelos profissionais e pela família, essas informações. Outra evidência foram os casos de Dora e Lia, que relizaram duas cirurgias, uma quando criança e outra na fase da adolescência.
Para se referirem à amputação de clitóris, falaram também da 'pelinha que tiraram', já à plástica vaginal, referiram-se com a terminologia correta, a cirurgia realizada para 'abrir a vagina que era muito fechada'.

O que sentiu em relação ao procedimento cirúrgico são as emoções embutidas ao pré e pós operatórios.

"Não lembro... quer dizê, o médico falou assim que se eu não fizesse ia crescer. Aí que, por isso que eu fiquei naquela dúvida, né? Assim, não ia crescer, mas porque crescer? Não sei... se eu paro de tomá o remédio, cresce, por isso que eu fico com aquela dúvida, então eu sou homem ou eu sou mulher? Mulher.. mulher não tem nada disso, né? Não cresce nada, nem cresce nem diminui, né? Então... eu tenho dúvida...” (Taís)

"Ah, melhorô, melhorô, assim... é que ainda eu tô usando o molde... Ah, foi bom, né? (...) Ah, é um pouco chato, né? Mas me disseram que tem que usar, então... Você tem que colocá ele na vagina, senão ela pode fechá, e tem que fazê outra cirurgia. (...) Eu coloco ele a noite... Ah! Não acontece nada, porque nem incomodá não incomoda. (...) Ah, é estranho, né? Mas tem que usá mesmo, aí (suspiro) é estranho. (...) (risos) Ah! É ruim ter que colocar uma coisa em você para, para melhorar, é... mas não é nada..." (Lia)

Além de sentirem vergonha da equipe médica e o incômodo pelo uso do molde vaginal, mais uma vez vem à tona a confusão dessas mulheres, ao terem que lidar com seus sentimentos. Essa confusão parte da busca da normalidade, perpassando o anormal, o diferente, em direção ao conformismo.

Outro fato foi o procedimento cirúrgico ter se mostrado como um ponto crucial no questionamento da Taís em relação ao seu papel sexual. A partir do momento em que ela apreendeu a cirurgia como indispensável ao aspecto feminino da sua genitália, ela passou a questionar sua feminilidade.

Expectativa quanto ao tratamento é a esperança nas possibilidades da terapêutica médica.

"Eu esperava, no início, depois do tratamento que eu fizesse, né? Terminasse, mas pelo que eles me falaram, eu vou ter que fazer o tratamento pra sempre, né? Que eu não poso parar...” (Lena)

"sou menina normal, queria podê pará de tomá o remédio e usá o molde." (Dora)

"Ah! Eu espero que eu não precise mais dele. Pará de tomá o remédio e í de vez em quando no hospital, né? É isso que eu espero." (Lara) 
Apesar de reconhecerem ser uma esperança utópica, todas esperam parar um dia com o medicamento e ter alta do hospital. No fundo desejam a cura da HCSR.

A menstruação mostra como as mulheres portadoras de HCSR encaram esse marco no desenvolvimento feminino.

"Eu me formei com 14 anos, né? E desdaí tive menstruação irregular. E desde sempre (...) foi seguindo assim, até quando eu soubesse do problema e fizesse o tratamento." (Lena)

"Teve mês que passava, né? Aí vinha outro mês. Assim, né? Mas agora tá vindo normal, agora." (Lara)

Para elas, foi uma decorrência normal do desenvolvimento, fato até, muitas vezes, aguardado, enquanto corroboração da feminilidade. No entanto, as menstruações desregradas acabam trazendo um certo desconforto, é mais um sintoma da síndrome, interferindo no enfrentamento da doença.

A causa da síndrome, aquilo que elas creditaram como sendo a origem, a razão, e/ou o motivo de serem portadoras de HCSR.

"O quê?? Na minha cabeça, sem explicação, né? É genético, uma mutação genética, e a minha irmã já não teve. (...) Então aí entra um pouco de Deus na vida da gente, no qual eu acredito muito... Então, se a gente tem que tê uma cruz pra carregá, essa foi a que Deus me deu... no seguinte sentido, de te limitá, né? Porque não vai falá que você faz e acontece porque, num faz e acontece." (Susi)

"Ah! Isso aí é um... dos genes do pai e da mãe. Acho que meu pai tinha, minha mãe tinha $e$ aí como os dois tinha... deu a doença. Então, eu já li também em livros, é isso, vem do pai e da mãe mesmo. (O que sente:) Ah! (risos) não sei né? Ah... não posso culpar eles por nada, né? (Lia)

As participantes relataram alguma confusão, mas partiram corretamente em direção à causa genética, apontando para a família, que acreditavam ser a transmissora do gene.

A fala da Susi foi impregnada de dogmatismo, uma vez que trouxe também a causa como um 'castigo divino', como 'a cruz que tem que carregar'.

O que sente em relação à $\mathbf{H C S R}$ contempla como as mulheres se percebiam no momento da entrevista, enquanto portadoras da síndrome.

"É, tem que í seguindo... eu penso assim... né? Que nem quem tem uma diabete, tem outra coisa, eu tenho a hiperplasia, então, eu tenho que aprendê a lidar com isso, e tocá em frente..." (Lena)

"É o que eu tô te falando, dúvida, né? É o que eu tô te falando... às vezes eu fico meio cisma$d a$, será que eles (médicos) estão me escondendo alguma coisa, que não qué que eu saiba, então é difícil. Mas é aquela coisa (...) ah! Sente, você sente, eu já fiquei meio assim, né? Já tenho esse problema aqui em baixo, então, já tenho que ficá grilada, então se eles (médicos) falarem que eu tenho isso que nem homem, eu não tenho, lógico, então eu fico mais aliviada." (Taís)

$$
\text { "Ai... não sei te falá... (risos)" (Bete) }
$$

Demonstraram confusão, evidenciada na dicotomia normal-anormal, diferente-igual, homem-mulher. E, na busca do conformismo, da compensação (no caso de Dora), crendo até mesmo, como no caso da Susi, num Deus que limita os atributos físicos para tolher o desenvolvimento da pessoa como um todo.

Dificuldade em falar sobre a problemática traz os impedimentos, os obstáculos presentes na abordagem da HCSR com os amigos e familiares.

"Minha mãe e meu pai, só. (...) É segredo!"

\section{(Dora)}

"Sinto. (...) Ah, lá em casa só..." (Bete)

Os entraves em estar falando sobre a síndrome num contexto social foram observados somente nas entrevistas das mulheres solteiras. Esse fato pode estar relacionado à questão da aceitação da síndrome aliada ao papel sexual. A partir do momento em que essas mulheres possuem um parceiro, elas se assumem como portadoras da síndrome, trazendo o assunto, inclusive para o âmbito social, uma vez que se sentem resguardadas sexualmente, pelo fato de serem casadas.

Início de vida sexual é definida como a primeira vez em que tiveram um relacionamento sexual completo, ou seja, quando perderam a virgindade.

"Porque os meninos só qué... vamo dizê assim, eles só qué transá com você e falá pros amigo, né? Então, com meu problema é difícil, né?" (Lia)

"Ah! Gostaria de não tê por enquanto... por causa do meu problema, né? Até explicá pro meu parceiro, então eu prefiro não tê." (Lara)

A idade variou de 17 a 28 anos. Para Lia e Lara, a síndrome configura-se como a principal dificuldade ao primeiro relacionamento, permeado pelo 
segredo que se alia à doença e pela desconfiança nos parceiros.

A decisão de iniciar vida sexual traz a experiência da resolução de começar atividade sexual, ou o ato sexual propriamente dito.

"Foi difícil... a gente começou a namorar, já tava com quase nove, dez meses que a gente tava namorando, né? E eu sentia apoio, porque fica a curiosidade, né? Então foi o que rolou, foi uma coisa boa, pra mim foi uma coisa boa." (Lena)

Foi uma decisão difícil, que, necessariamente, veio aliada à confiança no parceiro e à resolução de contar aos parceiros sobre a HCSR.

Quem não tem parceiro: vai contar sobre a HCSR? Às mulheres portadoras de HCSR, que não tiveram experiência sexual é explorado se, no futuro, vão contar para os possíveis parceiros sobre a síndrome.

"Não, não vai saber..." (Dora)

"Aí eu vô explicá pra ele, né? Se ele entendê, bem, se não, aí... separo. Largo!" (Lara)

As opiniões se dividiram. Dora e Bete colocaram como um segredo e que parceiro nenhum vai ficar sabendo. Lia colocou que vai contar para o parceiro com quem for casar, ou seja, manter um relacionamento mais sério. Mesma situação a da Lara, no entanto, ela é muito mais clara, que se o futuro parceiro não entender: '... separo. Largo!' (de uma forma até hostil). A atitude de Lara e Lia pode significar insegurança e, novamente, o medo de serem anormais, e se contam ao parceiro e ele não compreende, as suposições podem se confirmar.

Sente prazer e têm orgasmos é definida pela sensação prazerosa do ato sexual ou da masturbação e se a sensação chega ao ápice do orgasmo.

"Tudo direitinho..." (Susi)

"Sinto, mais ou menos..." (Dora)

Todas as entrevistadas sentem prazer e têm orgasmos. Essas vivências foram relatas livremente ou deixadas implícitas nas atitudes das entrevistadas no momento da entrevista. Esse era um impasse, que justificava a realização deste trabalho, e, através do resultado, pôde-se supor uma possível plasticidade para a manutenção da área erógena.

A valorização da imagem corporal, ou seja, a atribuição de valores em termos do que gosta e do que não gosta em sua imagem corporal.

"Eu gostava... do que eu era. Aí depois que eu engordei, eu acho que eu fiquei meio chata, não... não gosto muito do que eu vejo não. Acho meio..." (Lena)
"Viche! Do meu corpo eu não gosto de nada não... O que eu não gosto... da minha barriga (bate na barriga- risos). Da minha b. que é muito grande, isso aqui grandão. Mas eu não consigo perdê." (Lara)

As mulheres não estavam satisfeitas com o corpo, que não se adequava aos padrões de beleza vigentes, principalmente se ligados à magreza. Confundiram essa não satisfação com o corpo, com traços de suas personalidades ('agora que eu estou gorda eu sou chata').

No entanto, as mulheres com HCSR trazem a necessidade do conformismo com essa não satisfação, como um sinal de que, portanto, estão aceitando a síndrome.

O que gostaria de mudar no corpo é definido pelas mudanças que fariam para sentirem-se satisfeitas com sua imagem corporal.

"Ah, não. Eu me acostumei desse jeito, já me propuseram mudá... fazer um tratamento para melhorar minha voz, mas eu falei a vida inteira desse jeito, cantei, como é que eu vô fazê?? Não! Eu não quero. Inclusive, já falei, não lembro em que ocasião aí: 'vamo fazê um tratamento aí?' Não, que tratamento! Tratamento pra eu acabá ficando muda, aí? Deixa eu falá desse jeito!" (Susi)

\section{"Hum... Tudo..." (Bete)}

Algumas mulheres não pontuaram esse ou aquele aspecto, disseram querer mudar tudo e essa mudança, muitas vezes, trouxe indícios de mudanças de personalidade também. O regime foi o primeiro colocado, como sendo o que mudaria mais o corpo, mas, como usam corticóides cronicamente, esse comportamento veio embuído de muito sofrimento. Alguns sintomas da síndrome também foram alvos de desejo de mudanças, mas, logo após, foi colocada a expressão do conformismo.

Com que sexo gostaria de ter nascido traz a opção de ser homem ou mulher e a explicação do motivo da opção.

"Eu sempre falo em casa que na próxima encarnação eu queria sê homem. (Ser mulher:) Ah, eu acho que é uma carga meio pesada. Só problema, só dificuldade, eu acho difícil ser mulher. Acho que é uma coisa muito difícil, em tudo, né? Hoje tá difícil pra você sê mãe, pra você fazê tudo tá difícil. Então é uma coisa que pesa muito. Acho que ser homem é mais fácil (risos) ah, é!" (Lena)

"Mulher mesmo... ah! Mulher pode ter filhos, aprender a cozinhar." (Dora) 
As respostas foram sempre distintas, a Lena e a Lara gostariam de ter nascido homem e explicaram que por causa das "regalias" sociais do sexo. As demais gostariam de ser mulheres, também devido às "regalias sociais", "regalias" essas que diferiram, ou seja, para as que gostariam de ser homem essas não eram "regalias", mas "prejuízos" (ser mãe, ter que cozinhar, ficar em casa, lavar banheiro).

\section{4- DISCUSSÃO}

As mulheres portadoras de HCSR, entrevistadas demonstraram entendimento sobre a síndrome, causas, sintomas, o tratamento e o prognóstico da síndrome. No entanto, essa compreensão não extrapola às questões emocionais, fazendo com que "dúvidas" perpassem sua rotina.

As mulheres relatam sentirem dúvidas, porém não conseguem nomeá-las, demonstrando a carga emocional, despendida frente ao tratamento médico, com intervenções cirúrgicas, reposições hormonais e crônicas, enfim, trazem embuídos o questionamento de uma papel sexual masculino ou feminino.

De acordo com Bee $(1997)^{(2)}$, as fases do desenvolvimento sexual são prematuras. Aos 2 anos, as crianças já são capazes de se autonomearem meninos ou meninas, desenvolvendo a partir daí sua identidade de gênero. As mulheres com HCSR, em algum momento, e cotidianamente, através do uso da medicação, têm essa identidade questionada, podendo resultar nessa "sensação" de dúvida, de desconforto, que não conseguem nomear.

Além disso, a cirurgia é outro procedimento disparador de vários males emocionais, o que, também, é demonstrado no estudo de Vates et al., (1999)(4). Esse procedimento traz o alívio de talvez possuir uma genitália feminina, ao mesmo tempo que a insegurança de uma genitália que possa não ser "normal", potencializando o questionamento sobre sua feminilidade: "mulher que nasce mulher não precisa de cirurgia”. Como esse, nas entrevistas, pôde-se observar outros sentimentos ambivalentes, referentes a "normal-anormal", "diferente-igual", "como homemcomo mulher".

As mulheres que não fizeram a cirurgia, pois apresentavam uma genitália considerada "normal" pelos parâmetros médicos, relataram o desconforto de não sentirem a genitália como normal, uma vez que consideram ainda seu clitóris aumentado. Sentem, também, vergonha dos exames de rotina, além do medo de o clitóris voltar a crescer e uma possível descoberta desse clitóris pelos parceiros, gerando insegurança no início e dificuldades na manutenção de relacionamentos sexuais. Nesse sentido, o comportamento sexual dessas mulheres apresenta-se bastante comprometido, como demonstraram também, em seus estudos, Zucher et al. (1996) ${ }^{(6)}$. Elas têm medo da reação do parceiro ao seu problema de saúde, pois, além de inseguras quanto a sua feminilidade, sentem-se inseguras quanto à sua identidade de sexo e auto-imagem, isto é, não se reconhecem como mulher e demonstram-se descontentes com seu corpo. Para as mais novas e não casadas, os relacionamentos íntimos são mais desgastantes,pois perpassam pelo segredo da doença, pela camuflagem da medicação e dos sintomas, ficando evidentes os danos psicológicos, causados pela síndrome.

O medicamento, produz obesidade e, conseqüentemente, desfaz o sonho de um corpo esbelto, magro, trazendo sofrimentos, que são vividos e revividos diariamente, à hora da medicação. Esse descontentamento com o corpo interfere diretamente na imagem corporal dessas mulheres, pois, além de não se sentirem totalmente femininas, sequer podem sentirse valorizadas pela sua auto-imagem.

Os efeitos colaterais da medicação, principalmente a obesidade, fizeram com que algumas entrevistadas tivessem dificuldades na adesão ao tratamento.

Assim, a síndrome ou, mais pontualmente, conhecer o que essas mulheres sabem sobre a doença é importante para instrumentalizar os profissionais, envolvidos na equipe, sobre os problemas emocionais, que interferem no desenvolvimento dessas mulheres. Como se pode observar, o "ser portadora" da doença e os sintomas daí decorrentes, bem como o tratamento cirúrgico e medicamentoso trazem dificuldades nos âmbitos físico, emocional, social e sexual.

Dessa maneira, além de ser importante o diagnóstico precoce da doença, para iniciar o mais cedo possível os tratamentos, interferindo o menos possível na etapa de aquisição da identidade de gênero da criança, fica também evidenciada a importância de um psicólogo, na equipe, que conheça as dificuldades pelas quais passam as pacientes portadoras de HCSR, e no atendimento a elas e às famílias, tranquiilizando-as e apoiando-os nas dificuldades emocionais que possam existir. É importante, também, que esse profissional sirva de ponte entre paciente e equipe, para alertar sobre as dinâmicas demandadas. 
BRUNHARA FCR \& PETEAN EBL. Congenital adrenal hiperplasia: The diagnosis comprehension and autoimage implications. Medicina, Ribeirão Preto, 36: 45-53, jan./march, 2003.

ABSTRACT: The congenital adrenal hyperplasia $(\mathrm{CAH})$ is a genetic syndrome characterized as a condition of intersexuality. Seven womem with $\mathrm{CAH}$ were individually interviewed, under care of the clinic for Determination and Sexual Differentiation of HCFMRP-USP the aim of this alway was evaluate how they knew about the $\mathrm{CAH}$. The women aged from eighteen to forty years old, five underwent genital corrective surgery, and all women belong to a low social and cultural status and education. The results indicated some kind of understanding about the syndrome. Four single women did not initiate their sexual life and three of them claimed that the syndrome was the major difficulty for that. All women did not refer physical prejudice related to vulva reconstitution and they were capable to have pleasure and orgasms.

UNITERMS: Adrenal Hyperplasia, Congenital. Diagnosis, Psychology. Self Concept.

\section{REFERÊNCIAS BIBLIOGRÁFICAS}

1 - GRÜNSPUN H. Distúrbios de identidade de gênero da infância e da adolescência. In: ASSUMPÇÃO Jr FB. Psiquiatria da infância e da adolescência. Maltese Editora, São Paulo, 1994.

2 - BEE H. O ciclo vital. Artes Médicas, Porto Alegre, 1997.

3 - AMERICAN PSYCHIATRY ASSOCIATION-DSM-IV. Manual diagnóstico e estatístico de transtornos mentais. Tradução Dayse Batista, $4^{\mathrm{a}}$ ed. Artes Médicas, Porto Alegre, 1995.

4 - MEYER BAHLBURG HFHF; GRUEN RS; NEW MI; BELL JJ; MORISHIMA A; SHIMSHI M; BUENO Y; VARGAS I \& BAKER SW. Gender change from female to male in classical congenital hyperplasia. Horm Behav 30: 319-332, 1996.

5 - VATES T S; FLEMING P; LELESZI J P; BARTHOLD J S; GONZÁLEZ R \& PERLMUTTER AD. Functional, social and psychosexual adjustment after vaginal reconstruction. J Urol 162: 182-187, 1999.

6 - SLIJPER FME \& DROP SLS. Long-term psychological evaluation of intersex children. Arch Sex Behav 27: 125-144, 1998.

7 - ZUCKER KJ; BRADLEY SJ; OLIVER G; BLAKE J; FLEMING S \& HOOD J. Psychosexual development of women with congenital adrenal hyperplasia. Horm Behav 30: 300-318, 1996.
8 - ALHERBISH AS; ALJURAYYAN NAM; BAKR AMA; ABDULLAH MA; ALHUSAIN M; ALRABEAH AA; PATEL PJ; JAWAD A \& ALSAMARRAI Al. Sex reassignment: A challenging problem - Current medical and Islamic guidelines. Ann Saudi Med 16: 12-15, 1996.

9 - ALHERBISH AS; ALJURAYYAN NAM; BAKR AMA \& ABDULLAH MA. Congenital adrenal hyperplasia due to 21 hydroxylase deficiency: Consequences of delayed diagnosis - Can it be prevented?. Saudi Med J 17: 66-69, 1996.

10 - MINAYO M C S. O desafio do conhecimento: Pesquisa qualitativa em psicologia. Hucitec/Abrasco, São Paulo/ Rio de Janeiro, 1994.

11 - VALLES MS. Técnicas cualitativas de investigacion social - Reflexion metodologica e practica profesional. Editorial Síntesis, Madrid, 1997.

Recebido para publicação em 12/09/2002

Aprovado para publicação em 31/03/2003 